\title{
REIMER, Ivoni Richter. Maria, Jesus e Paulo com as mulheres: textos, interpretações e história. São Leopoldo: CEBI; São Paulo: Paulus, 2013. 101p. ISBN:: 978-85-3493-673-6
}

Carolina Bezerra de Souza*

Ivoni Richter Reimer é professora dos programas de pós-graduação em Ciências da Religião e História Cultural da Pontifícia Universidade de Goiás. Doutorou-se em Teologia e Filosofia na Alemanha, graduou-se em Teologia pela Escola Superior de Teologia, em São Leopoldo. A autora é também pastora na Igreja Evangélica de Confissão Luterana do Brasil, assessora do CEBI e do SAB (Serviço de Animação Bíblica) de Paulinas e bolsista de produtividade do CNPQ. Possui diversos livros e artigos publicados nas áreas de exegese e hermenêuticas bíblicas, história antiga, movimento de Jesus, comunidades cristãs originárias e teologias e hermenêuticas feministas.

O livro, fazendo uso de uma linguagem extremamente acessível, aborda a questão da participação das mulheres nos cristianismos originários partindo daquela mulher mais conhecida, Maria, a mãe de Jesus. Divide o tema em três capítulos e uma introdução. 
O primeiro capítulo faz uma revisão do que é dito sobre Maria na Bíblia, tanto por Paulo como nos Evangelhos, também nos textos apócrifos e no Corão. Paulo trata de Maria para destacar a encarnação do Verbo; os evangelhos e o livro de Atos a têm como modelo de fé e de prática. Os textos apócrifos tratam da concepção virginal tanto de Maria como de Jesus e mostram que nas igrejas medievais ela ainda era considerada discípula e apóstola. Já no Islã, ela é modelo de pureza e dedicação a Deus, mas vista como Mãe de Jesus e não de Deus. Em seguida, localiza Maria em meio a uma história de mulheres, presentes na genealogia de Jesus em Mateus, que se tornam transgressoras pela solidariedade e dedicação a Deus. São retomados novamente os retratos de Maria nos Evangelhos canônicos para mostrar que os primeiros textos cristãos, como Marcos, não a tratam como virgem, mas como a mãe de Jesus que se dedica à construção de uma nova cultura, mas Mateus e Lucas trazem a virgindade e uma gravidez sem a ideia da procriação para que Deus apresentasse corporeidade.

O segundo capítulo já trata das mulheres dentro dos movimentos cristãos originários, usando o referencial da memória em perspectiva de gênero para trabalhar as relações de poder nesses grupos. A partir das memórias percebidas nos textos bíblicos, notam-se, dentro do cristianismo primitivo, duas tendências político-eclesiais: uma nas tábuas domésticas de algumas cartas, que submetem as mulheres aos homens e as excluem das funções eclesiais; e outra nos evangelhos, que insistem no protagonismo das mulheres no movimento de Jesus, principalmente a partir do fenômeno visionário de serem as primeiras testemunhas da ressurreição. Esta experiência é silenciada por Paulo e assim se configura uma concorrência entre o apostolado de Maria Madalena, Joana e Maria de Tiago com Paulo e Pedro. A tradição dogmática apologética paulina teve primazia na tradição interpretativa e doutrinária da Igreja, o que leva à gradativa e incisiva exclusão das mulheres dos ministérios eclesiais ordenados. Isso caracteriza um problema de relações de poder em torno da identidade religiosa. 
O terceiro capítulo trata da reconstrução da pertença e participação das mulheres no movimento de Jesus e nos cristianismos originários. As mulheres foram acolhidas no movimento profético, carismático, sapiencial popular e itinerante de renovação judaica liderado por Jesus e tornaram-se discípulas através do seguimento e da diaconia, e apóstolas comissionadas nas cenas da ressurreição, como registrado, inclusive com seus nomes, em textos dos evangelhos, Atos e Romanos. Faz então uma análise do texto de Rm 16,1-6, que testemunha o trabalho missionário e de liderança das mulheres meio a uma cultura em que esse tipo de relação não era comum. Esse e outros textos precisam continuar ser revisitados como a autora faz neste livro.

O livro Maria, Jesus e Paulo com as mulheres faz uma reflexão fundamental sobre a participação e a interdição das mulheres no cristianismo, trabalhando diversos textos com referenciais teóricos bem fundamentados. Seu conteúdo traz ao leitor o desafio de prosseguir no desvelamento da presença e das experiências de mulheres nos cristianismos originários, e também no cristianismo atual, em busca construir, rever e refazer novas relações. Trata-se, portanto, de uma obra dinâmica e instigante, recomendada a todos os que desejem enveredar pela análise das relações de poder dentro do cristianismo. 